\title{
The Form of Debt and Stock Returns: Empirical Evidence from Oman
}

\author{
Khamis H. Al-Yahyaee ${ }^{1}$, Toan M. Pham ${ }^{2} \&$ Terry S. Walter ${ }^{3,4}$ \\ ${ }^{1}$ College of Economics and Political Science, Sultan Qaboos University, Muscat, Oman \\ ${ }^{2}$ Australian School of Business, University of New South Wales, Sydney, Australia \\ ${ }^{3}$ School of Business, University of Technology Sydney, Sydney, Australia \\ ${ }^{4}$ Member Services, Sirca Limited, Sydney, Australia \\ Correspondence: Khamis Al-Yahyaee, College of Economics and Political Science, Sultan Qaboos University, \\ Muscat, Oman, P. O. Box 20, P. C. 123, Muscat, Oman. E-mail: yahyai@squ.edu.om
}

\author{
Received: May 17, 2013 \\ Accepted: June 4, 2013 \\ Online Published: June 20, 2013 \\ doi:10.5539/ijef.v5n7p9 \\ URL: http://dx.doi.org/10.5539/ijef.v5n7p9
}

\begin{abstract}
This paper empirically examines whether stock prices have a significant effect on different forms of debt in a unique environment that is characterized by high leverage and high reliance on bank debt. Furthermore, firms in Oman are taxed at a flat rate and there are no personal income taxes. Our results show that stock returns have a significant effect on all types of debt. Debt ratios seem to move in line with that mechanistically induced by their stock returns. We also find new evidence that firms do take countermeasures to offset changes in their leverage that stem from equity value variations but at a low speed. Adding previously popular determinants of capital structure has only a modest economic impact on capital structure dynamics. When used with bank debt, stock returns continue to dominate other determinants of capital structure.
\end{abstract}

Keywords: Oman, capital structure dynamics, stock returns, issuing activity, bank debt

\section{Introduction}

There is growing evidence that stock prices have a significant and a persistent impact on firms' capital structure choice. In this vein, Welch (2004) finds that firms are basically inert and their capital structure changes are mainly driven by their stock returns. Moreover, he documents that firms do not issue debt or equity to counter the effect of stock returns on their capital structure. Welch also shows that after controlling for stock return effects, many previously used proxies play a minor role in explaining capital structure dynamics. Similarly, Kayhan \& Titman (2007) find that stock returns have a strong effect on capital structure and these effects are persistent for at least 10 years. Drobetz \& Pensa (2007) used a panel of 425 European firms and find that half of the variations in market value based leverage measures can be explained by stock returns.

In this paper, we investigate the impact of stock returns on different forms of debt using unique data from Oman. Specifically, we investigate whether firms' debt ratios move in line with that mechanistically induced by their stock returns using separate measures of short-term debt, long-term debt, total debt, and bank debt. The reason for separating debt into different components is that different theories have different empirical implications in regard to different types of debt instruments (Titman \& Wessels, 1998). Moreover, the vast majority of theoretical models on the choice of debt structure assume that bank debt and non-bank debt are equivalent, and as a result most empirical studies either exclude bank debt or combine it with non-bank debt (Hooks \& Opler, 1993). In this study, a distinction is made between bank debt and non-bank debt in an effort to enhance our understanding about the characteristics of firms that use these different funding mechanisms. This distinction is important since it is possible that bank debt may exhibit different characteristics than non-bank debt.

Oman is of interest for many reasons. First, Oman has unique financing arrangements that are characterized by high leverage and high reliance on bank debt (Al-Yahyaee, 2006). The finance literature argues that banks are particularly good at investigating informationally-opaque firms and deciding which are viable borrowers. Banks have an advantage in collecting (private) information but are potentially more expensive sources of capital than public debt markets. The costs of monitoring and imperfect financial contracting should raise the cost of debt for firms borrowing from banks, and hence lower their debt ratios (Faulkender \& Petersen, 2006). The empirical fact that Omani firms remain highly levered is surprising given the cost of bank borrowing in Oman. 
Second, due to the simplicity of the tax system, Oman provides an "interesting laboratory" to test financial theories. In Oman there are neither personal income taxes nor taxes on investment income such as dividends and capital gains. This differs from most western countries, where a majority of capital structure studies are undertaken, which are characterized by complex tax codes, thus making it hard to isolate the importance of debt. In fact, Myers (1984, p. 588) concludes after reviewing the available empirical work that "(there is) no study clearly demonstrating that a firm's tax status has a predictable, material effect on its debt policy. I think the wait for such a study will be protracted." Further, Graham (2000, p. 1901) notes that "researchers face several problems when they investigate how tax incentives affect corporate financial policy and firm value. Chief among these problems is the difficulty of calculating corporate tax rates due to data problems and the complexity of the tax code. Other challenges include quantifying the effects of interest taxation at the personal level". While complexity is true for the US, it is clearly not true for Oman where firms are taxed at flat rate of $12 \%$ and individuals are not taxed at all (Note 1). Thus, Oman offers an environment that enables a researcher to avoid tax rate complications. A finding of a positive association between leverage and taxes would help in addressing one aspect of the capital structure puzzle (Graham, Lemmon, \& Schallheim, 1998).

Apart from the contribution to the sparse literature on capital structure in emerging markets, this study extends the capital structure literature along a number of dimensions. First, while there is a wide agreement that stock returns are an important determinant of capital structure, there is an intensive debate on whether this effect is persistent. These findings are mainly derived using data from the US. We provide independent evidence from Oman. Second, in comparison to previous work on this topic, we examine a broader set of explanatory variables and introduce factors that are unique to Oman. Much of the analysis is devoted to determining which variables are economically important in predicting leverage, with a central focus on stock returns. The primary objective of the study is to examine whether stock returns are important factors in firms capital structure choices for different forms of debt. The relationship between debt ratios and stock returns is investigated with various determinants commonly found in previous studies, such as firm size, type of asset, growth opportunities, profitability, uniqueness, etc. Moreover, since the theories have different empirical implications in regard to different types of debt instruments, our study uses separate measures of short-term, long-term and an aggregate measure of leverage to show the robustness of our experiment. Third, the simplicity of the tax code in Oman provides us with a unique opportunity to avoid the complexities faced by previous studies. These may enable us to get clearer results on the impact of taxes on capital structure.

Our results show that stock price changes have a significant effect on all types of market-based debt ratios. Specifically, firms' debt ratios seem to move in line with that mechanistically induced by their stock returns for short-term debt, long-term debt and total debt. We also find that firms show some tendency to revert to their previous debt ratios. However, the impact of stock returns dominates the effects of readjustment.

Adding previously suggested popular determinates of capital structure has only modest economic impact on capital structure dynamics. In essence, when we include these variables into our model, stock returns subsume these other factors. Nevertheless, there are non-stock return variables that have both statistical and economic significance. For example, corporate taxes show some incremental explanatory power in our 5-year regressions. However, the impact of taxes is far less than that of stock returns. When used with bank debt, stock returns continue to subsume other determinants of capital structure.

Leary \& Roberts (2005) argues that the persistent effect of shocks to leverage documented in previous studies is due to adjustment costs. We examine these results and find evidence that adjustment costs are unlikely to be the main reason behind our results. In a similar vein, Flannery \& Rangan (2006) claim that the Fama \& MacBeth (1973) (F-M) regression used in Welch fail to recognize the panel aspect of their data. They argue that a partial adjustment model with fixed effects is a more appropriate estimator. We employ Flannery \& Rangan's model and estimate it using F-M, fixed effects, and General Method of Moments (GMM). We find that our results are robust to these methods. In general, our result that stock returns are a primary determinant of capital structure is consistent with the recent work by Cai \& Zhang (2006), Chen \& Zhao (2005), and Kayhan \& Titman (2007). The slow adjustment we find is in line with the evidence reported by Jalilvand \& Harris (1984), Fama \& French (2002), Baker \& Wurgler (2002), Titman \& Tsyplakov (2007), and Huang \& Ritter (2009).

In a recent study, Al-Yahyaee, Pham \& Walter (2013) examine capital structure dynamics in Oman and they find that stock returns have a significant effect on capital structure. This study differs from that of Al-Yahyaee et al. (2013) in two major aspects. First, we examine the effect of stock returns on different forms of debt which is not done in their study. Second, we include in this study other determinants of capital structure suggested by the literature to examine whether these have economic relevance, after controlling for the effects stock returns. If one of these variables appears to have no incremental power when stock returns are controlled for, then it would 
have correlated with capital structure only indirectly through its correlation with stock returns. This important issue has not been investigated in Al-Yahyaee at al. (2013).

The remainder of the paper proceeds as follows. Section 2 describes the data and presents the measures that we construct to estimate the impact of stock returns on capital structure dynamics. Section 3 develops the regression specification, and examines whether the form of debt matters and presents the estimation results. Section 4 presents the results for the determinants of change in leverage followed by an investigation of the extent to which these effects hold with bank debt in Section 5. In Section 6 we provide comparison with the current literature. Section 7 concludes the paper.

\section{Data and Methodology}

\subsection{Data}

The data for this study are taken from "Share-Holding Guide of MSM Listed Companies" published by the Muscat Securities Market (MSM). The MSM collects annual financial statements and stock price data for all firms listed on MSM. We complement the data from the MSM Guide with the MSM index which we obtain from the MSM.

The data set comprise all publicly traded firms listed on the MSM in the four industry sectors that comprise the MSM namely, financial and banking sector, service sector, industry sector, and insurance sector. These sectors contain firms from various industries including hotels, poultry, leasing, fisheries, oil, agriculture, energy, power, aviation, banks, investment firms, and manufacturing firms. The data are time series cross-sectional variables which are collected over the entire life of the MSM from 1989 to 2003.

Any observations with missing data for the book value of debt, and/or market value of equity are deleted because these variables are required to calculate our dependent and independent variables. Because our regression specification includes lagged variables, we also exclude any firm with fewer than two consecutive years of data. The number of firms included in the study changes from one year to another, with a range from 60 to 142 . The final data set is an unbalanced panel containing 1,263 firm-year observations.

\subsection{Measures of Leverage}

The definition of leverage is important since an ill-defined measure of debt may not only lead to spurious relationships, but also, and more importantly, not allow the full response of the firms to be captured (Plesko, 2001). Several definitions of leverage have been used in the literature, with most studies using a long-term debt ratio. A frequent difference between studies is whether book value measures or market value measures are employed. Most of the current academic literature focuses on market debt ratios (e.g., Hovakimian, Opler, \& Titman, 2001, Frank \& Goyal, 2009; Welch, 2004; Leary \& Roberts, 2005; Hovakimian, 2006; Flannery \& Rangan, 2006), whereas the older literature tends to focus on book value (e.g., Rajan \& Zingales, 1995; Booth, Aivazian, Demirguc-Kunt, \& Maksimovic, 2001). Theory suggests that market value is a more reliable measure of leverage because it deflates debt levels by the present value of the firm's equity, as reflected in current stock market valuations, that is, it reflects the present value of the firm's expected future cash flows. In fact, Welch (2002) provides evidence that book value of equity is a problematic measure of firm value because US accounting methods do not reflect changes in the value of assets on a timely basis. Welch (2002) also shows that book value of equity has a low correlation with the market value of equity. Consequently, this study employs market value of equity to calculate leverage ratios.

\subsection{Empirical Model}

Similar to Al-Yahyaee et al. (2013), our objective in this paper is to examine whether variation in the market leverage ratio is caused primarily by stock returns or deliberate managerial choices to adjust to their past target debt ratios. The basic empirical model is a time series cross sectional regression of firms' debt ratios against the lagged market leverage ratio and the stock return induced changes in market value of equity. This estimating equation extends the model used by Welch (2004) to Oman. As with previous studies, the dependent variable in our regressions is market leverage ratio or as Welch calls it the Actual Debt Ratio $\left(\mathrm{ADR}_{\mathrm{t}}\right)$. We define accounting measures in accordance with Welch (2004). Specifically, ADR is defined as the ratio of book value of debt $(D)$ scaled by the book value of debt and the market value of equity $(E)$ :

$$
A D R_{t}=\frac{D_{t}}{D_{t}+E_{t}}
$$

where $D_{t}$ is the sum of current liabilities and long-term liabilities at time $t$ and $E_{t}$ is the market value of equity at time $t$ (computed as the number of outstanding shares multiplied by the market price). As in Welch (2004), our 
explanatory variables are the lagged $A D R$ and the $\operatorname{IDR}_{t, t+k}$. IDR $\mathrm{IDt}_{\mathrm{t}, \mathrm{k}}$ is the implied debt ratio that results if the firm does not adjust its leverage, i.e., it neither issues nor retires debt or equity. It is constructed to measure the extent to which market leverage ratios are expected to change in response to stock returns. By construction, IDR moves mechanistically with stock returns, and not with managerial capital structure decisions. Consistent with Welch (2004) notation, the IDR is:

$$
I D R_{t, t+k}=\frac{D_{t}}{E_{t} \cdot\left(1+x_{t, t+k}\right)+D_{t}}
$$

where $D_{t}$ and $E_{t}$ are as defined above, $x_{t, t+k}$ is the stock return from $t$ to $t+k$ net of any dividend, , and k is the horizon measured in years.

Hence, the basic regression equation in Welch (2004) is:

$$
A D R_{t+k}=\alpha_{0}+\alpha_{1} \cdot A D R_{t}+\alpha_{2} \cdot I D R_{t, t+k}+\epsilon_{t}
$$

where $\epsilon_{t}$ is a random error.

As in Welch (2004), perfect readjustment implies that $\alpha_{1}=1, \alpha_{2}=0$, while perfect inertia suggests $\alpha_{1}=0, \alpha_{2}=1$. As robustness checks, we also perform the analysis separately on short-term debt, long-term debt, and bank debt.

Under the hypothesis of optimizing behavior and zero adjustment costs, the readjustment hypothesis reflects a target that managers wish to achieve each period. On the other hand, the inertia (non-readjustment) hypothesis implies that any change in leverage between $t$ and $t+k$ is due to the stock return over the period. We estimate equation (3) twice, with and without an intercept. When we include the intercept $\alpha_{0}$, it captures a constant target debt ratio. If firms manage their capital structure to maximize the advantage of debt for the shareholders, then the coefficient on ADR should be unity. On the other hand, if debt ratios are driven mechanistically by stock returns, then the coefficient on IDR should be unity.

\section{Estimation Results}

\subsection{Regression Specification}

To avoid overstating significance levels by pooling the data over time, we employ the Fama \& MacBeth (F-M) (1973) regression approach. Under this methodology, we first run yearly cross sectional regressions. We then report the mean coefficient estimates across time and use the time series standard deviation of the slopes in the year-by-year regressions to compute standard errors. The main advantage of this approach is that it circumvents the problems caused by heteroscedasticity and correlation of residuals across firms (Lipson \& Mortal, 2009). Fama \& French $(2002$, p. 3) describe F-M as "a simple way to obtain robust standard errors that capture whatever contributes to the precision of the average slopes". Another advantage of this approach is that it enables us to have a large number of data points. This increases the precision of the slopes and reduces their year-by-year volatility (Fama \& French, 1998). However, as Fama \& French (1998) note, this approach suffers from the problem that the sample autocorrelation of the slopes is imprecise. They account for the autocorrelation of the regression slopes by requiring a $t$-statistic of around three to infer reliability. In this study, we closely follow this approach. We are also concerned that the regressions may suffer from extreme observations. We winsorize the distributions at the $2^{\text {nd }}$ and $98^{\text {th }}$ percentile for variables with extreme values, consistent with Welch (2004).

\subsection{Does the Form of Debt Matter?}

The main objective of the paper is to examine whether stock returns have a significant effect on different forms of debt. Specifically, we investigate whether firms' capital structures move in line with that mechanistically induced by their stock returns for short-term debt, long-term debt, total debt, and bank debt. As explained above, the reason for separating debt into different components is that different theories have different empirical implications in regard to different types of debt instruments (Titman \& Wessels, 1998).

To examine this issue, we estimate equation (3) by using first only short-term debt, second, long-term debt, third, total debt and fourth, bank debt in the calculation of the dependent variable.

The results presented in Table 1 shows that a large fraction of time variation in the level of leverage stems from movements in stock returns for all forms of debt. In particular, the coefficients on IDR are much higher than for ADR for all types of debt. The coefficient estimates of stock returns do not vary much across different definitions of debt, being in the range of $57 \%$ for bank loans to $69 \%$ for long-term debt. The average firm show some tendency to move back towards its past debt ratio. However, the effect of stock returns dominates the effect 
of readjustments. The evidence that stock returns have a primary effect on capital structure is similar to the results reported in Al-Yahyaee et al. (2013).

We also examine whether the form of debt matters using five year data (unreported) and we find similar results to those for the one year horizon. In particular, we find that the coefficients on IDR exert more influence on firms' debt ratios than ADR, indicating that stock return influences dominate the effects of rebalancing regardless of the form of debt over a 5-year horizon.

Table 1. Alternative debt definitions

\begin{tabular}{lllllllll}
\hline Type of Debt & constant & $\mathrm{ADR}_{\mathrm{t}}$ & $\mathrm{IDR}_{\mathrm{t}, \mathrm{t}+\mathrm{k}}$ & s.e.c $_{\text {. }}$ & s.e.ADR & s.e.IDR & Adjusted $\mathrm{R}^{2}(\%)$ & $\mathrm{T}$ \\
\hline Short-term Only & 7.2 & 15.8 & 67.7 & 0.7 & 4.2 & 4.1 & 69.0 & 14 \\
Long-term Only & 5.9 & 12.6 & 68.6 & 0.6 & 5.1 & 5.0 & 67.3 & 14 \\
Total Debt & 9.2 & 15.0 & 68.3 & 0.8 & 3.8 & 3.7 & 71.7 & 14 \\
Bank Loan Only & 7.2 & 15.5 & 57.1 & 0.7 & 5.5 & 5.3 & 54.8 & 14 \\
\hline
\end{tabular}

Description: The sample comprises all publicly listed firms at the MSM between 1989-2003. The table presents the results of annual cross-sectional regressions explaining firms' debt ratios (debt dividend by debt plus market value of equity) with the implied debt ratio IDR (where the lagged market value of equity is grossed up by the raw stock return over the period $\mathrm{k}$ ) and the firms own lagged debt ratio $\mathrm{ADR}_{\mathrm{t}}$. The cross-sectional regression equation is: $A D R_{t+k}=\alpha_{0}+\alpha_{1} \cdot A D R_{t}+\alpha_{2} \cdot I D R_{t, t+k}+\epsilon_{t}$. A coefficient of $100 \%$ on $\mathrm{ADR}_{\mathrm{t}}$ indicates perfect readjustment. On the other hand, a coefficient of $100 \%$ on $\mathrm{IDR}_{\mathrm{t}, \mathrm{t}+\mathrm{k}}$ indicates perfect lack of readjustment. We report Fama \& MacBeth (1973) means (across years) of the regression intercepts and slopes. The adjusted $\mathrm{R}^{2} \mathrm{~s}$ are time-series averages of cross-sectional estimates. $\mathrm{T}$ is the number of cross-sectional regressions. There are 1,212 firm-year observations.

If we compare the results across different types of debt, the results show that the impact of stock returns are quite similar on all types of debt. Further, the effect of readjustment towards past debt ratios are also similar for all types of debt. In sum, the results demonstrate that firm debt ratios appear to be driven more by stock returns than by a conscious return to their past debt ratios for all types of debt. This does not mean that firms do not try to rebalance. In fact, firms in our sample show some tendency to return to their old debt ratios. However, the impact of stock returns dominates the effects of adjustments for all forms of debt.

Since the results are similar for all types of debt, we proceed in our analysis using only total debt as our dependent variable in the next sections.

\subsection{Can Adjustment Costs Explain the Inertia Behavior?}

Welch's (2004) paper spurned several subsequent studies that were either critical of his approach and/or suggested alternative explanations for his findings. For example, Welch did not consider the costs faced by firms in readjusting their capital structure. In the presence of adjustment costs, firms may find it suboptimal to respond immediately to capital structure shocks (Leary \& Roberts, 2005). Leary \& Roberts (2005) describe three types of adjustment costs namely, fixed cost, proportional cost, and a fixed cost plus a convex cost component. The proportional cost component is considered relative to the market value of raised or retired debt whereas the fixed cost is independent of the size of the transaction. Due to the fixed cost component, it is commonly argued that larger firms face relatively lower adjustment costs than smaller firms (Huang \& Ritter, 2009). Accordingly, we would expect larger firms to adjust their capital structure more frequently $(\mathrm{Xu}, 2007)$. We examine this issue by splitting our sample into two subsamples depending on whether the firms are smaller or larger than the median firm in the same year. A similar approach is used by Huang \& Ritter (2009). We then estimate equation (3) for both subsamples. We also consider the Altman Z-score as a proxy for adjustment costs as in Leary \& Roberts (2005) (Note 2). Firms with a higher (lower) Altman Z-score should be subject to lower (higher) bankruptcy costs and thus should face lower (higher) transaction costs. This implies that these firms should adjust more (less) frequently.

It is clear from Table 2 that larger firms, supposedly with lower adjustment costs, are not more eager to adjust. Similarly, firms with higher Altman Z-scores should be subject to lower adjustment costs and thus adjust more frequently. This is not what we observe in column 4 and 5. Firms with higher Altman Z-scores show no greater tendency to readjust compared to firms with lower Z-scores. The results are robust when the sample is split on the mean, rather than the median. This evidence suggests that adjustments costs are not a major explanatory factor for our results. 
Table 2. Can adjustment costs explain the inertia behavior?

\begin{tabular}{lllll}
\hline Variable & Small Size & Large Size & Low Z-score & High Z-score \\
\hline $\mathrm{ADR}_{\mathrm{t}}$ & 0.111 & $0.120^{*}$ & 0.135 & $0.124^{*}$ \\
$\mathrm{IDR}_{\mathrm{t},+1}$ & $0.759^{* * *}$ & $0.730^{* * *}$ & $0.714^{* * *}$ & $0.744^{* * *}$ \\
\hline Adjusted $\mathrm{R}^{2}$ & 0.753 & 0.687 & 0.759 & 0.657 \\
$\mathrm{~N}$ & 605 & 607 & 607 & 605 \\
$\mathrm{~T}$ & 14 & 14 & 14 & 14 \\
\hline
\end{tabular}

Description: The sample comprises all publicly listed firms at the MSM between 1989-2003, divided into (i) small and large firms and (ii) low and high Altman Z-score subsamples. The table presents the results of annual cross-sectional regressions explaining firms' actual debt ratios (debt dividend by debt plus market value of equity) with the implied debt ratio IDR (where the lagged market value of equity is grossed up by the raw stock return over the period $\mathrm{k}$ ) and the firms own lagged debt ratio $\mathrm{ADR}_{\mathrm{t}}$. The cross-sectional regression equation is: $A D R_{t+k}=\alpha_{0}+\alpha_{1} \cdot A D R_{t}+\alpha_{2} \cdot I D R_{t, t+k}+\epsilon_{t} \cdot$ A coefficient of $100 \%$ on $\mathrm{ADR}_{\mathrm{t}}$ indicates perfect readjustment. On the other hand, a coefficient of $100 \%$ on IDR $_{\mathrm{t}, t+\mathrm{k}}$ indicates perfect lack of readjustment. The sample is split up according to whether firm specific characteristics such as size and financial distress costs is lower or higher than the year-specific sample median. Size is defined as log of assets and Altman Z-score is defined as the reciprocal of assets divided by the sum of 3.3 times earnings before interest and taxes plus sales plus 1.4 times retained earnings plus 1.2 times working capital. We report Fama \& MacBeth (1973) means (across years) of the regression intercepts. The adjusted $\mathrm{R}^{2}$ 's are time-series averages of cross-sectional estimates. $\mathrm{N}$ is the number of firm year observations and $\mathrm{T}$ is the number of cross-sectional regressions.

Notes: * The Fama-MacBeth-type $t$-statistic is above 3. ${ }^{* *}$ The Fama-MacBeth-type $t$-statistic is above $4 .{ }^{* * *}$ The Fama-MacBeth-type $t$-statistic is above 5 .

We also examine whether transaction costs can explain the inertia behavior using five year data (unreported) and we find qualitatively similar results to those reported for the one year. Specifically, we find that large firms adjust more slowly than small firms. Similarly, we find that firms with higher Z-scores adjust less frequently compared to firms with lower Z-scores. These results are consistent with Huang \& Ritter (2009) who find that firms with lower adjustment costs do not adjust faster than firms with higher adjustment costs. Similarly, Xu (2007) finds that large firms do not appear to adjust more quickly than small firms for the US. These results differ from Leary \& Roberts (2005) who argue that adjustment costs can explain the persistence effects of shocks in leverage.

\subsection{Variance Decomposition}

The focus of the analysis up to this point has been to explain the level and dynamics of debt ratios. However, it is possible to isolate the dynamic components of capital structure changes. In this section, we explore which of the dynamic components listed in Table 3 are responsible for changes in capital structure.

Table 3 contains the time series averages of R-squares from Fama-MacBeth regressions with the dynamic components as explanatory variables for both level of, and changes in, debt ratios. The results suggest that past debt ratios are an important explanatory variable of debt ratios dynamics. In particular, $64.8 \%$ of a firm's capital structure level can be explained by last year's capital structure. However, the history of firm's capital structure is able to explain only $21.3 \%$ in the 5 -year horizon. More importantly, the results show that corporate issuing activity is more important than stock-return induced changes in capital structure. Over annual horizons, stock returns are able to explain $22.2 \%$ of the change in debt ratios, whereas all net issuing activities together are able to explain around $64.9 \%$ of changes in debt ratios. This suggests that CFOs are quite active in the capital market.

Over a 5-year horizon, stock returns are able to explain $17.2 \%$ of debt ratio changes, while all net issuing activities are able to explain around $48 \%$. Table 3 also suggests that debt issuing activity is more capital structure relevant than equity issuing activities. This evidence is consistent with the findings of Hovakimian (2006). Over both 1-year and 5-year horizons, short-term debt issuing is more capital structure relevant. However, over five years, equity issuing activities becomes as important as long-term debt issuing activities, yet still is less important than short-term debt issuing activities. 
Table 3. Explanatory power of components of debt ratios and debt ratio dynamics

\begin{tabular}{|c|c|c|c|c|}
\hline & \multicolumn{2}{|c|}{$\begin{array}{l}k=1 \text { Year, } \\
\text { Avg. Adjust. } \mathrm{R}^{2}\end{array}$} & \multicolumn{2}{|c|}{$\begin{array}{l}k=5 \text { Years, } \\
\text { Avg. Adjust } \mathrm{R}^{2}\end{array}$} \\
\hline & Levels & Differences & Levels & Differences \\
\hline 1. Past Debt Ratio, $\mathrm{ADR}_{\mathrm{t}}$ & $64.8 \%$ & & $21.3 \%$ & \\
\hline 2. Implied Debt Ratio, $\mathrm{IDR}_{\mathrm{t}, \mathrm{t}+\mathrm{k}}$ & $71.8 \%$ & $22.2 \%$ & $25.5 \%$ & $17.2 \%$ \\
\hline 3. Implied Debt Ratio, w/dividend & $70.7 \%$ & $20.1 \%$ & $25.4 \%$ & $6.4 \%$ \\
\hline 4. All issuing and dividend activity & $80.7 \%$ & $62.8 \%$ & $49.6 \%$ & $44.7 \%$ \\
\hline 5. All issuing activity & $87.0 \%$ & $64.9 \%$ & $62.5 \%$ & $48.0 \%$ \\
\hline 6. Net Equity Issuing Activity & $68.3 \%$ & $13.3 \%$ & $34.0 \%$ & $23.9 \%$ \\
\hline 7. Net Debt Issuing (NDI) Activity & $80.2 \%$ & $48.0 \%$ & $49.6 \%$ & $44.7 \%$ \\
\hline NDI Short-term Only & & $19.9 \%$ & & $29.5 \%$ \\
\hline NDI Long-term Only & & $18.6 \%$ & & $24.3 \%$ \\
\hline NDI Bank Loans Only & & $8.9 \%$ & & $21.0 \%$ \\
\hline
\end{tabular}

Description: The sample comprises all publicly listed firms at the MSM between 1989-2003. The table presents the time-series average adjusted $\mathrm{R}^{2}$ from cross-sectional Fama \& MacBeth (1973) regressions. In Levels, actual debt ratio $\left(\mathrm{ADR}_{\mathrm{t}+\mathrm{k}}\right)$ is explained by the Regressor. In Differences, change in leverage $\left(\mathrm{ADR}_{\mathrm{t}+\mathrm{k}}-\mathrm{ADR}_{\mathrm{t}}\right.$ is explained by the Regressor minus $\mathrm{ADR}_{\mathrm{t}}$. The ratio are defined as follows: row 1: $D_{t} /\left(D_{t}+E_{t}\right) ;$ row 2: $D_{t} /\left\lfloor D_{t}+E_{t} \cdot\left(1+x_{t, t+k}\right)\right\rfloor ;$ row 3: $D_{t} /\left[D_{t}+E_{t} \cdot\left(1+r_{t, t+k}\right)\right\rfloor ;$ row $4:$ $\left(D_{t}+T D N I_{t, t+k}\right) /\left(D_{t}+T D N I_{t, t+k}+E_{t}+E N I_{t, t+k}-D I V_{t, t+k}\right)$; row 5: $\left(D_{t}+T D N I_{t, t+k}\right) /\left(D_{t}+T D N I_{t, t+k}+E_{t}+E N I_{t, t+k}\right)$; row 6 : $D_{t} /\left(D_{t}+E_{t}+E N I_{t, t+k}-D I V_{t, t+k}\right) ;$ row $7:\left(D_{t}+T D N I_{t, t+k}\right) /\left(D_{t}+T D N I_{t, t+k}+E_{t}\right)$.

\section{Other Determinants of Capital Structure}

Having examined the impact of stock returns on capital structure dynamics, we now turn our attention to other variables suggested by the literature to examine whether these have economic relevance, after controlling for the effects of stock returns. If one of these variables appears to have no incremental power when IDR is controlled for, then it would have correlated with capital structure only indirectly through its correlation with stock returns.

In order to examine the impact of these variables on capital structure choice, we follow Welch (2004) by using two estimation models, namely, multivariate and four-variate. The multivariate model estimated is as follows:

$$
A D R_{t+k}-A D R_{t}=\alpha_{0}+\alpha_{1} \cdot X_{t, t+k}+\sum_{c=1}^{C}\left(\alpha_{2 c} \cdot V_{c_{t}}+\alpha_{2 c+1} \cdot V_{c_{t}} \times X_{t, t+k}\right)+\epsilon
$$

where $X_{t, t+k}=I D R_{t, t+k}-A D R_{t}$. The purpose of this variable is to measure the extent to which it can explain changes in market leverage ratio. Stated differently, $X_{t, t+k}$ measures the change in leverage that arises purely from stock returns. $V_{c}$ denotes a variable that supposedly influences the capital structure $\left(V_{c}\right.$ variables are described in detail in the Appendix) (Note 3). When a coefficient on $V_{c}$ is estimated to be significantly positive, $V_{c}$ incrementally helps to explain actual debt ratios. On the other hand, when the coefficient on $V_{c} \times X_{t, t+k}$ is positive, then $V_{c}$ incrementally helps to explain firms rebalancing tendencies towards their target. In addition, we run a four-variate regression with one $V_{c}$ variable at a time. The objective of the four-variate model is to avoid multicollinearity. The four-variate model estimated is as follows:

$$
A D R_{t+k}-A D R_{t}=\alpha_{0}+\alpha_{1} \cdot X_{t, t+k}+\alpha_{2} \cdot V_{c_{t}}+\alpha_{3} \cdot V_{c_{t}} \times X_{t, t+k}+\epsilon
$$

Table 4 provides estimates of the magnitudes of the changes in capital structure that are generated from both the multivariate and four-variate models. The coefficients are unit-normalized where the coefficients are multiplied by the standard deviation of the variable. As in the US, return-induced debt ratio changes have the largest effect on capital structure dynamics over one year. In economic terms, a one-standard deviation higher $\Delta \mathrm{IDR}$ is associated with $1.18 \%$ increase in debt ratio. Over an annual horizon, most of the variables included in the regression are statistically significant. However, these variables do not have much economic importance. None of the variables other than return-induced debt ratio changes have a coefficient greater than one percent. Return-induced debt ratio changes continue to have the largest effect on capital structure dynamics over a 5-year horizon. However, the magnitude of the effect of return-induced debt ratio changes over the 5 -year horizon is much higher $(8.08 \%)$ than the 1-year horizon $(1.18 \%)$ indicating larger economic importance. Three other interaction variables are both statistically and economically significant, namely future stock return reversal, depreciation, and the tax rate. However, their economic significance is far less than that of equity return induced debt ratio changes. 
Table 4. Fama-MacBeth regressions explaining debt ratio changes $\left(\mathrm{ADR}_{\mathrm{t}+\mathrm{k}},-\mathrm{ADR}_{\mathrm{t}}\right)$ adding variables used in prior literature

\begin{tabular}{|c|c|c|c|c|c|c|}
\hline Variable & Multivariate & Four-variate & Std. Dev. & Multivariate & Four-variate & Std. Dev. \\
\hline Intercept & $(0.004)$ & varies & & 0.359 & varies & \\
\hline \multicolumn{7}{|c|}{ (Flow Variables Measured from $t$ to $t+k$ ) } \\
\hline$\Delta \mathrm{IDR}=\mathrm{IDR}_{\mathrm{t}, \mathrm{t}+\mathrm{k}}-\mathrm{ADR}_{\mathrm{t}}$ & $1.181 * * *$ & varies & 0.102 & $8.084 * * *$ & varies & 0.043 \\
\hline Stock Return & -0.039 & -0.010 & 0.829 & -0.015 & -0.029 & 0.269 \\
\hline$\times \Delta \mathrm{IDR}$ & -0.057 & -0.080 & 0.106 & -0.010 & $-1.987^{*}$ & 0.012 \\
\hline 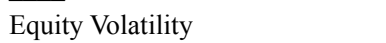 & $0.146^{* * *}$ & -0.002 & 0.630 & 0.001 & -0.015 & 0.528 \\
\hline$\times \Delta \mathrm{IDR}$ & -0.078 & -0.121 & 0.105 & -0.013 & -0.212 & 0.047 \\
\hline 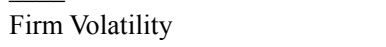 & $-0.185 * * *$ & -0.004 & 0.713 & -0.015 & $0.027 * * *$ & 0.592 \\
\hline$\times \Delta \mathrm{IDR}$ & 0.046 & -0.082 & 0.138 & -0.994 & -0.579 & 0.063 \\
\hline$\overline{\text { Profitability, Sales }}$ & $0.045^{* * *}$ & 0.006 & 1.137 & -0.147 & 0.031 & 0.583 \\
\hline$\times \Delta \mathrm{IDR}$ & 0.034 & 0.083 & 0.117 & 0.207 & -0.565 & 0.024 \\
\hline$\overline{\text { Profitability, Assets }}$ & -0.011 & 0.018 & 0.231 & 0.428 & $0.139 * *$ & 0.156 \\
\hline$\times \Delta \mathrm{IDR}$ & -0.006 & 0.060 & 0.021 & 0.009 & -2.199 & 0.007 \\
\hline$\overline{\text { Future Stock Return Reversal }}$ & $-0.042 * *$ & -0.015 & 0.513 & -0.032 & -0.119 & 0.084 \\
\hline$\times \Delta \mathrm{IDR}$ & 0.022 & 0.083 & 0.025 & -0.017 & $-4.561 * * *$ & 0.004 \\
\hline$\overline{\mathrm{PROF}}$ & -0.004 & 0.001 & 1.941 & $0.029 *$ & 0.004 & 1.191 \\
\hline$\times \Delta \mathrm{IDR}$ & 0.036 & $0.060^{*}$ & 0.171 & 0.041 & 0.064 & 0.079 \\
\hline \multicolumn{7}{|l|}{ (Stock Variables Measured at $t$ ) } \\
\hline Soft Loans & $0.023 * * *$ & 0.008 & 0.454 & $0.074 *$ & 0.049 & 0.392 \\
\hline$\times \Delta \mathrm{IDR}$ & 0.054 & $0.207 * * *$ & 0.049 & 0.024 & 0.210 & 0.017 \\
\hline Government Ownership & $-0.038 * * *$ & -0.043 & 0.127 & 0.031 & 0.071 & 0.152 \\
\hline$\times \Delta \mathrm{IDR}$ & 0.041 & 0.406 & 0.014 & 0.010 & -0.153 & 0.005 \\
\hline$\overline{\text { Dividend Payout Ratio }}$ & $0.019^{* *}$ & 0.003 & 1.026 & 0.014 & 0.001 & 1.439 \\
\hline$\times \Delta \mathrm{IDR}$ & -0.022 & -0.024 & 0.090 & 0.045 & 0.150 & 0.061 \\
\hline Return on Assets & $0.027 * * *$ & 0.039 & 0.188 & 0.114 & $0.191 * * *$ & 0.118 \\
\hline$\times \Delta \mathrm{IDR}$ & 0.004 & 0.079 & 0.018 & 1.032 & -2.744 & 0.005 \\
\hline$\overline{\text { Fixed Assets/Total Assets }}$ & -0.006 & 0.002 & 0.426 & -0.020 & -0.024 & 0.314 \\
\hline$\times \Delta \mathrm{IDR}$ & -0.041 & 0.040 & 0.049 & 0.022 & -0.205 & 0.018 \\
\hline$\overline{\log S a l e s}$ & $0.041^{* * *}$ & 0.008 & 0.762 & -0.016 & 0.020 & 0.652 \\
\hline$\times \Delta \mathrm{IDR}$ & $-0.253^{*}$ & -0.049 & 0.649 & 0.345 & 0.556 & 0.278 \\
\hline$\overline{\text { Depreciation/Total Assets }}$ & $-0.013 *$ & -0.014 & 0.112 & 0.010 & -0.421 & 0.027 \\
\hline$\times \Delta \mathrm{IDR}$ & -0.004 & -0.088 & 0.008 & 0.001 & $-2.922 * * *$ & 0.001 \\
\hline$\overline{\text { Current Assets/current Liabilities }}$ & $-0.028 * * *$ & -0.005 & 0.598 & $-0.415 * * *$ & $-0.113 * * *$ & 0.579 \\
\hline$\times \Delta \mathrm{IDR}$ & -0.051 & $0.299 * *$ & 0.071 & -0.027 & 0.046 & 0.023 \\
\hline$\overline{\text { Industry Deviation }}$ & $-0.031 * * *$ & -0.015 & 0.254 & 0.001 & $-0.042 * * *$ & 0.245 \\
\hline$\times \Delta \mathrm{IDR}$ & -0.026 & $0.637 * * *$ & 0.026 & -0.030 & 0.133 & 0.020 \\
\hline Tax Rate & -0.014 & 0.006 & 0.053 & 0.167 & $0.177 * * *$ & 0.126 \\
\hline$\times \Delta \mathrm{IDR}$ & 0.001 & 0.037 & 0.006 & -0.141 & $-3.336^{* * *}$ & 0.005 \\
\hline$\overline{\text { Book} / \text { Market Ratio }}$ & $-0.032 * * *$ & -0.004 & 1.617 & $-0.194 * * *$ & 0.005 & 1.489 \\
\hline$\times \Delta \mathrm{IDR}$ & 0.050 & 0.053 & 0.163 & -0.349 & -0.252 & 0.051 \\
\hline$\overline{\log }$ Assets & $-0.031 * * *$ & -0.008 & 0.655 & -0.093 & 0.031 & 0.633 \\
\hline$\times \Delta \mathrm{IDR}$ & $-0.489 * * *$ & -0.040 & 0.709 & -1.333 & -0.636 & 0.301 \\
\hline$\overline{\text { Interest Coverage }}$ & 0.021 & 0.001 & 2.314 & -0.250 & 0.001 & 2.18 \\
\hline$\times \Delta \mathrm{IDR}$ & -0.028 & -0.001 & 0.184 & $-0.357 * * *$ & -0.001 & 0.089 \\
\hline $\mathrm{N} ; \mathrm{T}$ & 1,$142 ; 14$ & Varies & & $586 ; 10$ & Varies & \\
\hline Adjusted $\mathrm{R}^{2}$ & $23.0 \%$ & Varies & & $50.6 \%$ & Varies & \\
\hline
\end{tabular}

Description: The sample comprises all publicly listed firms at the MSM between 1989-2003. The table presents the results of annual cross-sectional regressions explaining change in leverage by adding variables used in the prior literature. Except for the intercept, variables were unit normalized (coefficients were multiplied by the standard deviation of the intercept). The multivariate columns are the coefficients from one big specification, $A D R_{t+k}-A D R_{t}=\alpha_{0}+\alpha_{1} \cdot X_{t, t+k}+\sum_{c=1}^{C}\left(\alpha_{2 c} \cdot V_{c_{t}}+\alpha_{2 c+1} \cdot V_{c_{t}} \times X_{t, t+k}\right)+\in$. The four-variate columns are the coefficients from individual specifications, one variable $\mathrm{V}$ at a time, $A D R_{t+k}-A D R_{t}=\alpha_{0}+\alpha_{1} \cdot X_{t, t+k}+\alpha_{2} \cdot V_{c_{t}}+\alpha_{3} \cdot V_{c_{t}} \times X_{t, t+k}+\in \cdot$ The regressions are run for each year $t$. We report Fama \& MacBeth (1973) means (across years) of the regression intercepts and slopes. The adjusted $\mathrm{R}^{2}$ 's are time-series averages of cross-sectional estimates. $\mathrm{N}$ is the number of firm year observations and $\mathrm{T}$ is the number of cross-sectional regressions.

Notes: * The Fama-MacBeth-type $t$-statistic is above 3. ** The Fama-MacBeth-type $t$-statistic is above $4 .{ }^{* * *}$ The Fama-MacBeth-type $t$-statistic is above 5 . 
Over one year, the inclusion of almost all variables discussed in the literature seems to have only a small impact on the ability of the model to explain the variation in leverage as indicated by the adjusted $\mathrm{R}^{2}$. The adjusted $\mathrm{R}^{2}$ increases by only around $0.8 \%$ from $22.2 \%$ when only IDR is used to $23 \%$ when all other variables are included. Over a 5 -year horizon, the increase is more evident $(17.2 \%$ in the IDR-only regression, $50.6 \%$ when all other variables are included).

Having discussed the overall results, we briefly discuss the statistical significant variables included in the estimation.

\subsection{Oman Unique Variables}

Our analysis includes unique variables suggested by the institutional arrangements in the Oman economy. These variables include government ownership and soft loans. Over both annual and 5-year horizons, the coefficients on soft loans are statistically significant and positively correlated with the debt ratio. However, the magnitude of the effect is small indicating little economic importance. On the other hand, government ownership is statistically significant only over the one year horizon. Surprisingly, firms with one standard deviation higher government ownership decrease debt over one year by $0.04 \%$.

\subsection{Other Statistically Important Variables}

Future Stock Return Reversal - Future stock return reversal has some incremental explanatory power for capital structure dynamics over one year. This suggests that firms that reverse their stock price after the period under examination (i.e., firms with positive (negative) prior-period returns have negative (positive) subsequent returns) behave differently from firms that experience stock price continuation. The interaction variable shows some economic significance over five years, but it is far less than that of return induced debt ratio changes.

Industry - Industry deviation has some incremental explanatory power for capital structure dynamics over both one and five years. The sign on the proxy is negative. The negative coefficient indicates that firms are inclined to adjust towards their industry's debt ratio. Again, the magnitude of the effect of this variable is small, suggesting a modest economic effect on capital structure dynamics.

Equity and Firm Volatility - Over annual horizons, equity and firm volatility are statistically important in firm capital structure dynamics. The regressions indicate that firms experiencing high equity volatility increase their leverage. Firm volatility has the opposite impact. Although this effect does not moderate the importance of stock returns, it does indicate that firms may not rebalance towards their past debt ratios but towards debt ratios conservative enough to be in line with the experienced volatilities. While this variable has some statistical significance over five years, there is little economic significance.

Profitability - Three variables are used as proxies for profitability. Return on assets shows statistical significance over both annual and 5-year horizon. Sales based profitability shows some incremental explanatory power over one year and assets based profitability is statistically significant over five years. However, their magnitudes are small. A firm with an increase of one standard deviation in return on assets is likely to take on an additional $0.03 \%$ in debt ratio over one year. Sales and assets based profitability have similar effects on the debt ratio.

Liquidity - Liquidity seems to be statistically important in capital structure dynamics over both one and five years. The negative coefficient suggests that liquid firms are less levered. As with other variables, the statistical significance is not accompanied by economic importance, evidenced by the small coefficient on the current ratio.

Size - Both of the size proxies show statistical significance over one year. However, the statistical significance on both proxies vanishes over the 5-year horizon. Even though there may be statistical significance for these variables, there is no economic significance.

Tax - Taxes are neither statistically nor economically important in capital structure dynamics over one year. However, this variable is statistically significant over five years. This implies that in the long-run taxes are an important determinant of capital structure dynamics. Firms are likely to take on an additional $0.177 \%$ in leverage per one standard deviation increase in tax rates over five years. The interaction effects coefficient is economically important. However, its importance is still much less than return induced debt ratio changes.

NDTS - NDTS is statistically significant over one year. The negative coefficient implies that firms with higher NDTS employ less debt. Again, there is little economic significance, even though there is some statistical significance. However, the interaction variable is both statistically significant and economically important over 5 -year horizon. Nevertheless, the impact of it is still far less than that of return induced debt ratio changes.

Growth - Firms with high book-to-market (i.e., low growth) are associated with lower debt ratio. This variable 
has some incremental explanatory power over both one and five years. With regard to the magnitude effect of this variable on change in leverage, it is in line with other variables where the impact is small.

Signaling - Dividends show some incremental explanatory power in explaining capital structure dynamics over an annual horizon. The positive coefficient indicates that firms that pay high dividends are the ones that have higher borrowings.

In summary, the results in Table 4 demonstrate that return-induced debt ratio changes have the largest impact on capital structure dynamics. Though there are other variables that are statistically significant, none have much economic importance. Previous studies have argued that some of the above variables are important explanators of capital structure dynamics. Our explanation is that this importance is most likely caused by the correlation of these variables with the IDR. Once a mechanistically implied debt ratio in included, these variables lose their power.

\section{The Effect of Stock Returns on Bank Debt}

The evidence presented so far has shown that the impact of stock returns on capital structure dynamics dominates other factors. A natural question is to examine whether these results hold for bank debt, given that there are some studies that argue there are differences between the determinants of bank debt and non-bank debt (Denis \& Mihov, 2003; Faulkender \& Petersen, 2006). (Note 4)

To examine this issue, we estimate the models in Table 4 using only bank debt. The results are presented in Table 5. Over one year, as with the results in Table 4, return-induced debt ratio changes subsume other determinants of capital structure. The economic importance of this variable is slightly higher than its counterpart in Table 4. In economic terms, a one-standard deviation higher $\Delta$ IDR is associated with $1.21 \%$ increase in debt ratio. There are some variables that are statistically significant but the magnitude of the effect is economically small. For example, the negative coefficient on liquidity and profitability suggests a negative association with bank debt. Likewise, firms with growth opportunities tend to have lower bank debt and larger firms do not use much bank debt. On the other hand, equity volatility is associated with higher bank debt. Firm volatility has the opposite influence on bank debt.

Over five years, return-induced changes continue to have the largest impact on the bank debt ratio. The economic significance is much larger compared to the one year horizon. The statistical significance of some of the variables over one year disappears over five years with other variables having statistical importance. The negative coefficient on industry deviation suggests that firms that wander away from their industry debt ratio are eager to nudge back to it, and that firms that have higher firm volatility are borrowing more from banks. The positive coefficient on government ownership indicates that firms with higher government ownership obtain more bank loans. As with the one year horizon, larger firms are less dependent on bank debt. The future stock return proxy is both statistically and economically significant. This suggests that firms with large stock price reversals behave differently from firms that do not experience a reversal. Taxes have some incremental explanatory power over five years. However, the coefficient on this variable is economically small.

In summary, stock-return induced debt ratio changes have the largest impact on the bank debt ratio. Other variables have minor economic significance on capital structure dynamics. 
Table 5. Fama-MacBeth regressions explaining bank debt ratio changes $\left(\mathrm{ADR}_{\mathrm{t}+\mathrm{k}}-\mathrm{ADR}_{\mathrm{t}}\right)$ adding variables used in prior literature

\begin{tabular}{|c|c|c|c|c|c|c|}
\hline Variable & Multivariate & Four-variate & Std. Dev. & Multivariate & Four-variate & Std. Dev. \\
\hline Intercept & 0.068 & varies & & 0.359 & varies & \\
\hline \multicolumn{7}{|c|}{ (Flow Variables Measured from $t$ to $t+k$ ) } \\
\hline$\Delta \mathrm{IDR}=\mathrm{DR}_{\mathrm{t}, \mathrm{t}+\mathrm{k}}-\mathrm{ADR}_{\mathrm{t}}$ & $1.211^{*}$ & varies & 0.093 & $6.308 * * *$ & varies & 0.037 \\
\hline Stock Return & -0.056 & -0.011 & 0.829 & -0.053 & -0.029 & 0.269 \\
\hline$\times \Delta \mathrm{IDR}$ & 0.001 & -0.027 & 0.041 & -0.036 & -0.780 & 0.014 \\
\hline 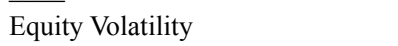 & $0.072 *$ & 0.001 & 0.630 & -0.064 & -0.024 & 0.528 \\
\hline$\times \Delta \mathrm{IDR}$ & 0.113 & 0.121 & 0.045 & -0.114 & -0.232 & 0.046 \\
\hline$\overline{\text { Firm Volatility }}$ & $-0.084 *$ & -0.013 & 0.713 & $1.587 * * *$ & $0.055^{* * *}$ & 0.592 \\
\hline$\times \Delta \mathrm{IDR}$ & -0.157 & 0.040 & 0.090 & 0.114 & 0.343 & 0.068 \\
\hline$\overline{\text { Profitability, Sales }}$ & $-0.034 * * *$ & -0.004 & 1.137 & -0.039 & 0.021 & 0.583 \\
\hline$\times \Delta \mathrm{IDR}$ & -0.065 & -0.047 & 0.104 & 0.296 & 0.155 & 0.025 \\
\hline$\overline{\text { Profitability, Assets }}$ & 0.038 & 0.027 & 0.231 & -0.265 & 0.095 & 0.156 \\
\hline$\times \Delta \mathrm{IDR}$ & 0.116 & $0.407 *$ & 0.023 & -0.055 & -0.268 & 0.007 \\
\hline$\overline{\text { Future Stock Return Reversal }}$ & -0.011 & 0.002 & 0.513 & 0.079 & $0.296 * * *$ & 0.084 \\
\hline$\times \Delta \mathrm{IDR}$ & 0.092 & $0.142 *$ & 0.121 & 0.104 & $1.743 * * *$ & 0.003 \\
\hline$\overline{\mathrm{PROF}}$ & 0.003 & -0.001 & 1.941 & -0.011 & 0.003 & 1.191 \\
\hline$\times \Delta \mathrm{IDR}$ & -0.036 & -0.004 & 0.154 & -0.008 & -0.029 & 0.044 \\
\hline \multicolumn{7}{|l|}{ 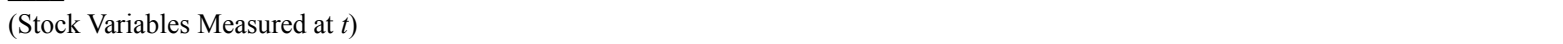 } \\
\hline Soft Loans & -0.015 & -0.001 & 0.454 & -0.032 & 0.005 & 0.392 \\
\hline$\times \Delta \mathrm{IDR}$ & 0.014 & -0.037 & 0.052 & 0.008 & 0.378 & 0.014 \\
\hline 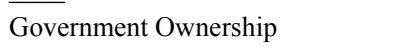 & 0.011 & 0.020 & 0.127 & $0.045 * * *$ & 0.064 & 0.152 \\
\hline$\times \Delta \mathrm{IDR}$ & -0.038 & -0.729 & 0.009 & 0.060 & $1.522 * * *$ & 0.006 \\
\hline$\overline{\text { Dividend Payout Ratio }}$ & -0.007 & -0.001 & 1.026 & 0.045 & 0.008 & 1.439 \\
\hline$\times \Delta \mathrm{IDR}$ & 0.029 & 0.034 & 0.095 & -0.017 & -0.057 & 0.061 \\
\hline$\overline{\text { Return on Assets }}$ & 0.018 & 0.030 & 0.188 & $-1.299 * * *$ & 0.143 & 0.118 \\
\hline$\times \Delta \mathrm{IDR}$ & 0.029 & 0.019 & 0.035 & $-0.401 * * *$ & 0.701 & 0.006 \\
\hline$\overline{\text { Fixed Assets/Total Assets }}$ & -0.012 & 0.005 & 0.426 & -0.033 & -0.027 & 0.314 \\
\hline$\times \Delta \mathrm{IDR}$ & 0.025 & -0.002 & 0.053 & -0.081 & -0.595 & 0.018 \\
\hline$\overline{\log S a l e s}$ & 0.009 & 0.004 & 0.762 & 0.050 & 0.036 & 0.652 \\
\hline$\times \Delta \mathrm{IDR}$ & 0.028 & 0.007 & 0.595 & 0.429 & 0.556 & 0.241 \\
\hline$\overline{\text { Depreciation/Total Assets }}$ & -0.027 & -0.053 & 0.112 & 0.021 & 0.249 & 0.027 \\
\hline$\times \Delta \mathrm{IDR}$ & 0.019 & 0.318 & 0.006 & 0.042 & $2.351^{* * *}$ & 0.001 \\
\hline$\overline{\text { Current Assets/Current Liabilities }}$ & $-0.037^{*}$ & -0.015 & 0.598 & 0.018 & 0.004 & 0.579 \\
\hline$\times \Delta \mathrm{IDR}$ & -0.031 & -0.018 & 0.048 & 0.064 & 0.700 & 0.027 \\
\hline Industry Deviation & 0.016 & 0.002 & 0.254 & -0.015 & $-0.120 * *$ & 0.245 \\
\hline$\times \Delta \mathrm{IDR}$ & 0.042 & $0.539 * *$ & 0.026 & -0.066 & -0.857 & 0.011 \\
\hline$\overline{\text { Tax Rate }}$ & -0.008 & -0.174 & 0.053 & 0.217 & $0.087 * *$ & 0.126 \\
\hline$\times \Delta \mathrm{IDR}$ & -0.015 & -0.751 & 0.006 & $-0.139 * * *$ & $-1.272 * * *$ & 0.005 \\
\hline$\overline{\text { Book} / \text { Market Ratio }}$ & $-0.015 *$ & -0.001 & 1.617 & -0.044 & 0.005 & 1.489 \\
\hline$\times \Delta \mathrm{IDR}$ & -0.022 & -0.021 & 0.148 & 0.039 & 0.149 & 0.058 \\
\hline$\overline{\log }$ Assets & $-0.046^{* * *}$ & -0.004 & 0.655 & $-0.903 *$ & 0.038 & 0.633 \\
\hline$\times \Delta \mathrm{IDR}$ & -0.047 & -0.059 & 0.644 & -0.091 & 0.069 & 0.254 \\
\hline$\overline{\text { Interest Coverage }}$ & 0.035 & 0.001 & 2.314 & 1.052 & 0.001 & 2.180 \\
\hline$\times \Delta \mathrm{IDR}$ & -0.026 & 0.001 & 0.195 & 0.202 & -0.001 & 0.096 \\
\hline$\overline{\mathrm{N} ; \mathrm{T}}$ & 1,$142 ; 14$ & Varies & & $586 ; 10$ & Varies & \\
\hline Adjusted $\mathrm{R}^{2}$ & $9.70 \%$ & Varies & & $14.90 \%$ & Varies & \\
\hline
\end{tabular}

the coefficients from individual specifications, one variable $\mathrm{V}$ at a time, $A D R_{t+k}-A D R_{t}=\alpha_{0}+\alpha_{1} \cdot X_{t, t+k}+\alpha_{2} \cdot V_{c_{t}}+\alpha_{3} \cdot V_{c_{t}} \times X_{t, t+k}+\in$. The regressions are run for each year $t$. We report Fama \& MacBeth (1973) means (across years) of the regression intercepts and slopes. The adjusted $\mathrm{R}^{2}$ s are time-series averages of cross-sectional estimates. $\mathrm{N}$ is the number of firm year observations and $\mathrm{T}$ is the number of cross-sectional regressions.

Notes: * The Fama-MacBeth-type $t$-statistic is above 3. ** The Fama-MacBeth-type $t$-statistic is above $4 .{ }^{* * *}$ The Fama-MacBeth-type $t$-statistic is above 5 . 


\section{Comparisons with the Current Literature}

There is an extensive debate on whether, and how quickly, firms rebalance their capital structure, with some studies reporting evidence supporting rebalancing and others failing to do so. Leary \& Roberts (2005) argue that firms respond to equity issuances and equity price shocks by rebalancing their leverage to stay within an optimal range. They argue that the persistence effects of shocks on leverage documented by Welch is more likely due to optimizing behavior in the presence of adjustment costs, as opposed to indifference towards capital structure. However, Chen \& Zhao (2005) thoroughly examine Leary \&Roberts (2005) findings and report evidence that contradicts the Leary \& Roberts (2005) results. Leary \& Roberts (2005) demonstrate through simulation that a firm's market leverage ratio can be driven by equity valuations because these firms do not rebalance constantly due to adjustment costs. It follows from this argument that we should observe firms with higher equity returns issuing more debt relative to equity than other firms when the adjustment boundaries are reached. Chen \& Zhao (2005) find the opposite - firms with higher equity returns are relatively more likely to issue equity. In general, Chen \& Zhao (2005) find that tradeoff theory does a poor job of explaining the issuance decisions, contradicting Leary \& Roberts (2005). In particular, they find both the key variables in tradeoff theory and the transaction cost variable predict issuance decisions the wrong way. They conclude that dynamic tradeoff theory with transaction costs is not likely to be the main interpretation for Welch's results. In a similar vein, Huang \& Ritter (2009) find that the effects of debt and equity issues on both book and market leverage last for more than 10 years, which is inconsistent with Leary \& Roberts (2005). Titman \& Tsyplakov (2007) develop a dynamic model of capital structure and report evidence that firms adjust their capital structure quite slowly. Similarly, Kayhan \& Titman (2007) find that stock returns have a strong effect on capital structure and these effects are at partially persistent for at least 10 years.

Using a similar argument to that of Leary \& Roberts (2005), Flannery \& Rangan (2006) report evidence that firms do target a long-run capital structure and the typical firm converges towards their long-term target at a rate of more than 30\% per year. Flannery \& Rangan (2006) suggest that Fama \& MacBeth (1973) regression employed by Welch fails to recognize the data's panel characteristics. They argue that a panel regression with unobserved (fixed effects) is more appropriate if firms have relatively stable unobserved variables influencing their capital structure targets. To examine whether our results are robust to their model, we estimate their partial adjustment model using Fama \& MacBeth (F-M) (1973) and fixed effects. The same variables in Table 4 are included in all estimation models, but not reported here. The first column in Table 6 reports the F-M estimates. The coefficient on lagged ADR implies that firm close $17.96 \%$ of the gap between current and desired leverage (Note 5). Stated differently, it takes around three years to close half the gap between a typical firm's current and desired leverage. This slow adjustment is consistent with our previous findings. This suggests that convergence towards a long-run target is unlikely to explain much of the variation in firms' debt ratios. The coefficient on SPE indicates that firms adjust by $14.94 \%$ of stock return surprises in the year they occur. This indicates that firms do try to counteract the influence of their own stock's return. While this result is different from the findings of Welch, it still suggests that the speed of adjustment to the stock price surprises is slow.

Following Flannery \& Rangan (2006), we estimate the partial adjustment model with fixed effects. The results are reported in column 2 of Table 6 . The estimated coefficients on the determinants of target leverage generally resemble their F-M counterparts. However, the estimated coefficient on ADR now implies a faster adjustment speed of $24.21 \%$. While this speed of adjustment is higher than that reported using F-M, it is still considerably less than that reported by Flannery \& Rangan (2006) of $34 \%$ for the US.

However, Hsiao (2003) and Baltagi (2005) demonstrate that fixed effects give biased estimates for the coefficients of the partial adjustment model. In particular, the estimated coefficient of the lagged dependent variable using fixed effects is biased downward. In other words, fixed effects models tend to overestimate the speed of adjustment. In this vein, Huang \& Ritter (2009) find that there is a substantial bias associated with the use of the fixed effects with a within-group estimator for a short panel. In essence, the estimated coefficients of the lagged dependent variable with firm fixed effects are biased downward, especially when the time dimension is short. They evaluate the magnitude of the bias and find that it is critically important to correct for the short-time dimension bias. 
Table 6. Flannery \& Rangan model explaining actual debt ratio $\left(\mathrm{ADR}_{\mathrm{i}, \mathrm{t}+1}\right)$ adding variables used in prior literature

\begin{tabular}{llll}
\hline Method & F-M & Fixed Effects & System GMM \\
\hline ADR & 0.8204 & 0.7579 & 0.7995 \\
& $(49.3698)$ & $(36.7177)$ & $(50.2737)$ \\
$\mathrm{SPE}=\mathrm{IDR}_{\mathrm{t}, \mathrm{t}+\mathrm{k}}-\mathrm{ADR}_{\mathrm{t}}$ & 0.8506 & 0.7986 & 0.8454 \\
& $(17.1700)$ & $(14.885)$ & $(28.9119)$ \\
\hline Adjusted $\mathrm{R}^{2}$ & 0.7188 & 0.6088 & - \\
Sargan test & & & 0.6750 \\
$m 1$ & & & 0.0002 \\
$m 2$ & & & 0.8713
\end{tabular}

Description: The sample comprises all publicly listed firms at the MSM between 1989-2003. The table reports the results of the estimated partial adjustment model explaining ADR by adding variables used in the prior literature. The model is: $A D R_{i, t+1}=a_{0}+\left(1-\lambda_{1}\right) A D R_{i, t}+\left(1-\lambda_{2}\right) S P E_{i, t+1}+\left(\lambda_{1} B\right) X_{i, t}+\mu_{i, t+1}$ where ADR is the actual debt ratio. IDR is the actual debt ratio at time $\mathrm{t}$ augmented by the firms return in $(\mathrm{t}, \mathrm{t}+1)$. SPE $=\mathrm{IDR}-\mathrm{ADR}_{\mathrm{i}, \mathrm{t}}$ measures the impact of price changes on ADR during $(\mathrm{t}, \mathrm{t}+1)$. The lagged " $\mathrm{X}$ " variables determine a firm long-run target debt ratio and include the untransformed variables in Table 4. T-statistics are presented in parentheses below the corresponding estimate. The first column is estimated using Fama-MacBeth methodology. The second column is using fixed effects and the last column is using system General Method of Moments. Reported R numbers for models including fixed effects are "within" $\mathrm{R}^{2}$ statistics. $m 1$ and $m 2$ are tests for first-order and second-order serial correlation, asymptotically N $(0,1)$. Sargan is a test of the over-identifying restrictions for the GMM estimators, asymptotically $\chi^{2}$. P-values are reported for $m 1, m 2$, and Sargan test. There are 1,142 firm-year observations.

A more appropriate method to deal with the problem of a short panel is to use GMM estimators (Anderson \& Hsiao, 1981; Arellano \& Bond, 1991; Arellano \& Bover, 1995). However, Blundell \& Bond (1998) suggest that the standard GMM can result in large finite-sample biases and poor precision in the estimators when used with highly persistent data series. They show that these biases could be dramatically reduced by applying the system GMM proposed by Arellano \& Bover (1995) (Note 6). Similarly, Blundell \& Bond (2000), Blundell, Bond, \& Windmeijer (2000), and Baltagi (2005) demonstrate that the system GMM produces more efficient results in finite samples than standard GMM estimators (Note 7). We adopt this method and we report the results in column 3 of Table 6 . According to the system GMM approach, the speed of adjustment is $20.05 \%$ (Note 8 ). This speed is slower than that reported using fixed effects. Most importantly, all results from the three estimation methods suggest that firms move towards target capital structure slowly. This evidence is in line with our previous results from Table 1. Thus, our results are robust to various method of estimation. Our results are similar to those reported by Huang \& Ritter (2009) who document that the speed of adjustment on market leverage decays at between $11 \%$ and $25 \%$ per year which they interpret as evidence of a slow adjustment.

\section{Conclusion}

We investigate whether stock returns have a significant effect on different forms of debt using a unique data set from Oman where (1) we avoid the complexity of tax systems faced by previous studies, and as a result may help us to provide clearer results on the impact of taxes on capital structure, (2) we introduce new variables that are unique to the country under analysis and (3) we distinguish between bank and non-bank debt.

We find several interesting results. First, we find firms are inert so they allow their debt ratios to drift with stock prices for all forms of debt. Second, we find that the average firm show some tendency to nudge back towards its past debt ratio. Still, the influence of stock returns dominates the effects of readjustments. Third, when included with other proxy variables (e.g., profitability, tangibility, etc.), stock returns dominate other terms in explaining capital structure dynamics. Some of these other explanatory variables suggested in the literature have statistical significance in Oman; however, the magnitude of their effect on the debt ratio is modest. For instance, taxes show some incremental explanatory power but this is far less than the impact of stock return over five years. Fourth, when the bank debt is used, the impact of stock returns continues to subsume other factors. Fifth, we examine Leary \& Roberts (2005) findings and we report evidence that adjustment costs are unlikely to be the main interpretation for our results. Finally, we show that our results are robust to the adjustments suggested by Flannery \& Rangan (2006) and Huang \& Ritter (2009).

\section{References}

Al-Yahyaee, K. (2006). Capital structure and dividend policy in a personal tax free environment: The case of Oman. (Unpublished doctoral dissertation). The University of New South Wales, Sydney, Australia.

Al-Yahyaee, K. (2013). The effect of a reduction in price discreteness on ex-day stock returns in a unique 
environment. Journal of International Financial Markets, Institutions \& Money, 23, 283-294. http://dx.doi.org/10.1016/j.intfin.2012.10.003

Al-Yahyaee, K., Pham, T., \& Walter, T. (2008). Ex-dividend day behavior in the absence of taxes and price $\begin{array}{llllll}\text { discreteness. } & \text { International } & \text { Review }\end{array}$ http://dx.doi.org/10.1111/j.1468-2443.2008.00078.x

Al-Yahyaee, K., Pham, T., \& Walter, T. (2011). The information content of cash dividend announcements in a unique environment. Journal of Banking \& Finance, 35, 606-612. http://dx.doi.org/10.1016/j.jbankfin.2010.03.004

Al-Yahyaee, K., Pham, T., \& Walter, T. (2013). Capital structure and stock returns: Evidence from an emerging market with unique financing arrangements. Applied Financial Economics, 23, 1197-1203.

Anderson, T., \& Hsiao, C. (1981). Estimation of dynamic models with error components. Journal of the American Statistical Association, 76, 598-606. http://dx.doi.org/10.1080/01621459.1981.10477691

Arellano, M., \& Bond, S. (1991). Some tests of specification for panel data: Monte-carloe evidence and an application to employment equations. Review of Economic Studies, 38, 277-297. http://dx.doi.org/10.2307/2297968

Arellano, M., \& Bover, O. (1995). Another look at instrumental-variable estimation error-components models. Journal of Econometrics, 68, 29-52. http://dx.doi.org/10.1016/0304-4076(94)01642-D

Baker, M., \& Wurgler, J. (2002). Market timing and capital structure. Journal of Finance, 62, 1-32. http://dx.doi.org/10.1111/1540-6261.00414

Baltagi, B. (2005). Econometric Analysis of Panel Data. New York: John Wiley and Sons.

Blundell, R., \& Bond, S. (1998). Initial conditions and moment restrictions in dynamic panel data models. Journal of Econometrics, 87, 115-143. http://dx.doi.org/10.1016/S0304-4076(98)00009-8

Blundell, R., \& Bond, S. (2000). GMM estimation with persistent panel data: An application to production functions. Econometric Review, 19, 321-340. http://dx.doi.org/10.1080/07474930008800475

Blundell, R., Bond, S., \& Windmeijer, F. (2000). Estimation in dynamic panel models: Improving on the performance of the standard GMM estimator. In B. Baltagi (Ed.), Advances in Econometrics 15: Non-Stationary Panels, Panel Cointegration, and Dynamic Panels. Amsterdam: JAI Elsevier Science. http://dx.doi.org/10.1016/S0731-9053(00)15003-0

Booth, L., Aivazian, V., Demirguc-Kunt, A., \& Maksimovic, V. (2001). Capital structures in developing countries. Journal of Finance, 56, 87-130. http://dx.doi.org/10.1111/0022-1082.00320

Cai, J., \& Zhang, Z. (2006). Capital structure dynamics and stock returns. Singapore Management University Working Paper. Retrieved from http://papers.ssrn.com/sol3/papers.cfm?abstract_id=685462

Chen, L., \& Zhao, X. (2005). Firm financing decisions. Michigan State University Working Paper. Retrieved from http://www.nber.org/papers/w10863.reftxt

Denis, D., \& Mihov, V. (2003). The choice among bank debt, non-bank private debt, and public debt: Evidence from new corporate borrowings. Journal of Financial Economics, 70, 3-28. http://dx.doi.org/10.1016/S0304-405X(03)00140-5

Drobetz, W., \& Pensa, P. (2007). Capital structure and stock returns: The European evidence. Working Paper. Retrieved from http://papers.ssrn.com/sol3/papers.cfm?abstract_id=957302

Fama, E., \& French, K. (1998). Taxes, financing decisions, and firm value. Journal of Finance, 53, 819-843. http://dx.doi.org/10.1111/0022-1082.00036

Fama, E., \& French, K. (2002). Testing tradeoff and pecking order predictions about dividends and debt. Review of Financial Studies, 15, 1-33. http://dx.doi.org/10.1093/rfs/15.1.1

Fama, E., \& MacBeth, J. (1973). Risk, return and equilibrium: Empirical tests. Journal of Political Economy, 81, 607-636. http://dx.doi.org/10.1086/260061

Faulkender, M., \& Petersen, M. (2006). Does the source of capital affect capital structure? Review of Financial Studies, 19, 45-79. http://dx.doi.org/10.1093/rfs/hhj003

Flannery, M., \& Rangan, K. (2006). Partial adjustment toward target capital structures. Journal of Financial Economics, 79, 469-506. http://dx.doi.org/10.1016/j.jfineco.2005.03.004 
Frank, M., \& Goyal, V. (2009). Capital structure decisions: Which factors are reliably important? Financial Management, 38, 1-37. http://dx.doi.org/10.1111/j.1755-053X.2009.01026.x

Graham, J. (1996). Debt and the marginal tax rate. Journal of Financial Economics, 41, 41-73. http://dx.doi.org/10.1016/0304-405X(95)00857-B

Graham, J. (2000). How big are the tax benefits of debt? Journal of Finance, 55, 1901-1941. http://dx.doi.org/10.1111/0022-1082.00277

Graham, J., Lemmon, M., \& Schallheim, J. (1998). Debt, leases, taxes, and the endogeneity of corporate tax status. Journal of Finance, 53, 131-161. http://dx.doi.org/10.1111/0022-1082.55404

Hooks, L., \& Opler, T. (1993). The determinants of corporate bank borrowing. Federal Reserve Bank of Dallas Financial Industry Studies Working Paper No. 1-93. Retrieved from http://ideas.repec.org/s/fip/feddfi.html

Hovakimian, A. (2006). Are observed capital structures determined by equity market timing? Journal of Financial \& Quantitative Analysis, 41, 221-243. http://dx.doi.org/10.1017/S0022109000002489

Hovakimian, A., Opler, T., \& Titman, S. (2001). The debt-equity choice. Journal of Financial \& Quantitative Analysis, 36, 1-24. http://dx.doi.org/10.2307/2676195

Huang, R., \& Ritter, J. (2009). Testing theories of capital structure and estimating the speed of adjustment. Journal of Financial \& Quantitative Analysis, 44, 237-271. http://dx.doi.org/10.1017/S0022109009090152

Jalilvand, A., \& Harris, R. (1984). Corporate behavior in adjusting to capital structure and dividend targets: An econometric study. Journal of Finance, 39, 127-145. http://dx.doi.org/10.1111/j.1540-6261.1984.tb03864.x

Kayhan, A., \& Titman, S. (2007). Firms' histories and their capital structure. Journal of Financial Economics, 83, 1-32. http://dx.doi.org/10.1016/j.jfineco.2005.10.007

Leary, M., \& Roberts, M. (2005). Do firms rebalance their capital structures? Journal of Finance, 60, 2575-2619. http://dx.doi.org/10.1111/j.1540-6261.2005.00811.x

Lemmon, M., Roberts, M., \& Zender, J. (2008). Back to the beginning: Persistence and the cross-section of corporate capital structure. Journal of Finance, 63, 1575-1608. http://dx.doi.org/10.1111/j.1540-6261.2008.01369.x

Lipson, M., \& Mortal, S. (2009). Liquidity and capital structure. Journal of Financial Economics, 12, 611-644.

Mackie-Mason, P. (1990). Do taxes affect corporate financing decisions? Journal of Finance, 44, 1471-1493. http://dx.doi.org/10.1111/j.1540-6261.1990.tb03724.x

Myers, S. (1984). The capital structure puzzle. Journal of Finance, 39, 575-592. http://dx.doi.org/10.2307/2327916

Plesko, G. (2001). The role of short-term debt in capital structure. Proceedings of the Ninety-Third Annual Conference, Washington D.C.: National Tax Association - Tax Institute of America, 135-140.

Rajan, R., \& Zingales, L. (1995). What do we know about capital structure? Some evidence from international data. Journal of Finance, 50, 1421-1460. http://dx.doi.org/10.1111/j.1540-6261.1995.tb05184.x

Share-Holding Guide of MSM Listed Companies. Muscat Securities Market, 1989 - 2005, Muscat, Oman.

Titman, S., \& Tsyplakov, S. (2007). A dynamic model of optimal capital structure. Review of Finance, 11, 401-451. http://dx.doi.org/10.1093/rof/rfm017

Titman, S., \& Wessels, R. (1988). The determinants of capital structure choice. Journal of Finance, 43, 1-19. http://dx.doi.org/10.1111/j.1540-6261.1988.tb02585.x

Welch, I. (2002). Columbus' egg: The real determinants of capital structure. National Bureau of Economic Research. Retrieved from http://www.nber.org/papers/w8782

Welch, I. (2004). Capital structure and stock returns. Journal of Political Economy, 112, 106-131. http://dx.doi.org/10.1086/379933

Xu, Z. (2007). Do firms adjust toward a target leverage level? Bank of Canada Working Paper No. 50. Retrieved from http://www.econstor.eu/handle/10419/538

\section{Notes}

Note 1. See Al-Yahyaee et al. (2008), Al-Yahyaee et al. (2011) and Al-Yahyaee (2013) for a detailed description of the tax system in Oman. 
Note 2. Altman Z-score is defined as the reciprocal of assets divided by the sum of 3.3 times earnings before interest and taxes plus sales plus 1.4 times retained earnings plus 1.2 times working capital. A similar measure is employed in Mackie-Mason (1990), Graham (1996), and Leary \& Roberts (2005).

Note 3. Besides the usual variables that explain capital structure, this study introduces two variables that are drawn from Oman unique corporate finance environment which are government ownership and soft loans. Firms with high government ownership may have lower bankruptcy costs. This is because the government may bail them out in case of trouble. Indeed, the agency theory postulates that the optimal structure of leverage and ownership may be used to minimize total agency costs. Hence, it is expected that there are some correlation between ownership structures and leverage. Moreover, the government ownership would give a confidence to lenders to extend loans to a company.

Besides government ownership, Oman subsidizes certain companies by giving them soft loans that are interest free. The eligibility of the company to get this subsidy increases its willingness to borrow. Consequently, a positive association between the availability of the soft loan and debt ratios should be expected (See Al-Yahyaee (2006) for a detailed description of the Oman unique variables).

Note 4. Faulkender \& Petersen (2006) show that the source of a firm's debt and whether it has access to public debt markets strongly affects its capital structure choice. In particular, they find that firms that have access to the pubic bond markets have significantly more debt.

Note 5. Our results are in line with that reported by Fama \& French (2002) where they find that the speed of adjustment is between 7 and 10\% for dividend payers and between 15 and $18 \%$ for dividend non-payers.

Note 6. Blundell \& Bond (1998) show that the biases can be dramatically reduced by exploiting reasonable stationary restrictions on the initial conditions process. These yields a system GMM estimator in which lagged first-differences of the series are used as instruments for the level equations, in addition to the usual lagged levels as instruments for equations in first-differences (Arellano \& Bover, 1995).

Note 7. See Baltagi (2005), Chapter 8 and Xu (2007) for a description of the system GMM.

Note 8. For the US, Lemmon, Roberts, \& Zender (2008) find that the speed of adjustment is $35 \%$ using firm fixed effects. However, the system GMM shows a much slower speed of adjustment of $21.4 \%$. Likewise, Xu (2007) documents that firms that rebalance over time adjust to their target capital structure slowly at $16 \%$ using the system GMM. 


\section{Appendix}

Variable Definitions

Definitions of variables

\begin{tabular}{|c|c|}
\hline Variable & Definition \\
\hline $\mathrm{D}_{\mathrm{t}}$ & The sum of current liabilities and long-term liabilities. \\
\hline $\mathrm{E}_{\mathrm{t}}$ & Market Value, the number of shares outstanding multiplied by the closing price at the end of the fiscal year. \\
\hline Assets & The sum of current assets and long-term assets. \\
\hline$A D R_{t}$ & Actual Debt Ratio: $D_{t} /\left(D_{t}+E_{t}\right)$ \\
\hline$I D R_{t, t+k}:$ Implied Debt Ratio & $D_{t} /\left[D_{t}+E_{t} \cdot\left(1+x_{t, t+k}\right)\right]$ \\
\hline$x_{t, t+k}$ & Stock returns without dividends, from “Oman Share-Holding Company’s Guide”. \\
\hline$r_{t, t+k}$ & Stock returns with dividends, from “Oman Share-Holding Company’s Guide”. \\
\hline$T D N I_{t, t+k}$ & Difference in total debt value: $D_{t+k}-D_{t}$ \\
\hline$E N I_{t, t+k}$ & Difference in total equity value sans return and dividend effects: $E_{t, t+k}-E_{t} \cdot\left(1+x_{t, t+k}\right)$. \\
\hline$D i v_{t, t+k}$ & $\left(r_{t, t+k}-x_{t, t+k}\right) \cdot E_{t}$ \\
\hline Government Ownership & Percentage of government ownership as obtained from “Oman Share-Holding Company’s Guide”. \\
\hline Signaling, Dividends & Dividend payment divided by net income. Winsorized at $2 \%$ and $98 \%$ \\
\hline Interest coverage & Earnings before interest and tax divided by interest expense. Winsorized at $2 \%$ and $98 \%$. \\
\hline Profitability, Assets & Operating income divided by total assets. Winsorized at $2 \%$ and $98 \%$. \\
\hline $\begin{array}{l}\text { Profitability, Return on } \\
\text { Assets }\end{array}$ & Net income dividend by total assets. Winsorized at $2 \%$ and $98 \%$. \\
\hline Profitability, Sales & Operating income divided by sales. Winsorized at $2 \%$ and $98 \%$ \\
\hline Profitability Changes & $\begin{array}{l}\text { Profitability divided by sales, an average from } t \text { to } t+k \text {, minus profitability divided by sales at } t-2 \text {. Not } \\
\text { winsorized. }\end{array}$ \\
\hline Tangibility & Property, plant, and equipment, divided by total assets. Winsorized at $2 \%$ and $98 \%$ \\
\hline Size, Sales & Log of sales. Not winsorized. \\
\hline Size, Assets & Log of total assets. Not winsorized. \\
\hline Non-debt Tax Shields & Depreciation expense dividend by total assets. Winsorized at $2 \%$ and $98 \%$. \\
\hline Growth & Book-to-market ratio; book value of equity divided by market value. Winsorized at $2 \%$ and $98 \%$. \\
\hline $\begin{array}{l}\text { Log Equity Volatility } \\
\text { Log Firm Volatility }\end{array}$ & $\begin{array}{l}\text { Standard deviation of returns. Timed from } t-1 \text { to } t \text {. Logged, not winsorized. } \\
\text { Equity Volatility multiplied by } E_{t} /\left(E_{t}+D_{t}\right) \text {. Logged, not winsorized. }\end{array}$ \\
\hline Soft Loans & A dummy of 1 if the firm receives a subsidy, and zero otherwise. \\
\hline Tax & Total income tax dividend by the sum of earnings and income tax. \\
\hline Industry Deviation & ADR of a firm minus the ADR average of the sector. \\
\hline Liquidity & Current assets dividend by current liabilities. \\
\hline $\begin{array}{l}\text { Future Stock Return } \\
\text { Reversal }\end{array}$ & Stock return from $t+k$ multiplied by stock returns from $t+k, t+2 k$. Not winsorized. \\
\hline
\end{tabular}

\section{Copyrights}

Copyright for this article is retained by the author(s), with first publication rights granted to the journal.

This is an open-access article distributed under the terms and conditions of the Creative Commons Attribution license (http://creativecommons.org/licenses/by/3.0/). 